\title{
The Role of Sex, Ethnicity, Age, and Nutritional Status in the Seropositivity of the Measles Vaccine
}

\author{
H. R. Teni Nurlatifah ${ }^{1,2 *}$, Wisnu Barlianto ${ }^{3}$ D, I. Wayan Arsana Wiyasa ${ }^{4}$, H. M. S. Chandra Kusuma ${ }^{3}$, Tita Luthfia Sari ${ }^{3}$, \\ Novilia Sjafri Bachtiar \\ ${ }^{1}$ Doctoral Program of Medical Science, Faculty of Medicine, Universitas Brawijaya, Malang, East Java, Indonesia; ${ }^{2}$ Department \\ of Applied Midwifery, Master's Study Program, STIKes Dharma Husada, Bandung, West Java, Indonesia; ${ }^{3}$ Department of \\ Pediatric, Faculty of Medicine, Brawijaya University, Malang, East Java, Indonesia; ${ }^{4}$ Department of Obstetrics and Gynecology, \\ Faculty of Medicine, Brawijaya University, Malang, East Java, Indonesia; ${ }^{5}$ Bio Farma, Bandung, West Java, Indonesia
}

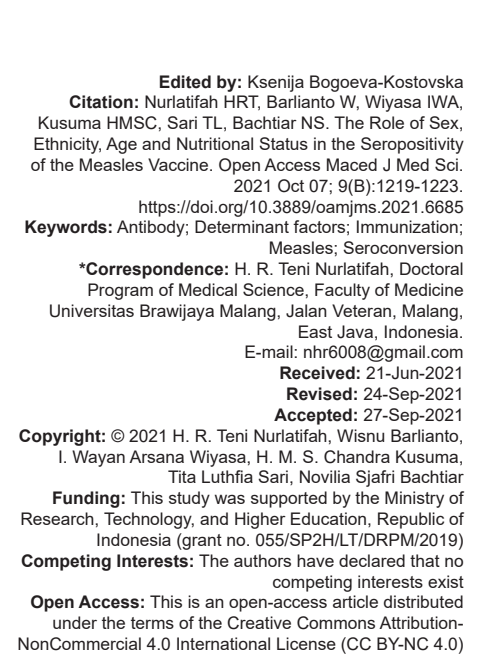

\section{Abstract}

AIM: This study investigates the relationship between sex, ethnicity, age, nutritional status with the seropositivity of the Edmonston-Zagreb vaccine in children.

METHODS: A cross sectional, observational study was conducted. A total of 45 children were differentiated based on sex, ethnicity, age, and nutritional status when they received the Edmonston-Zagreb measle vaccine for the firs time. Flow cytometry was used to look at differences in antibody status as well as populations of CD-4 and CD-8 cells that release IFN- $y$.

RESULTS: We found no significant differences in antibody levels or CD-4 and CD-8 cell populations that secrete IFN- $y$ between boys and girls $(p>0.05)$. Besides, similar results were also confirmed in comparisons between Javanese and Sundanese ethnic groups, 9 months versus more than 9 months of age, or normal versus low body mass index $(p>0.05)$.

CONCLUSIONS: We conclude that sex, race, age, and nutritional status had no effect on immune response to vaccination. As a result, there was no barrier to seroconversion and optimal immunological performance in the children in this trial who received the Edmonston-Zagreb measles vaccination.

\section{Introduction}

The measles virus is a single-stranded RNA paramyxovirus that enters the body and circulates systemically to suppress the body's immune response [1], [2], [3]. Measles complications include otitis media, pneumonia, and acute encephalitis [4]. Vaccination, herd immunity, and infection with wild-type viruses are three steps that can be taken to prevent measles infection [5]. Becaues the effect is extremely lethal on children, the World Health Organization (WHO) has designated elimination as its top priority. Measles elimination is achieved when no measles virus transmission is detected in a given area over a 12-month period under the supervision of an adequate surveillance system [6], [7].

In Indonesia, only $80 \%$ of people have been immunized against measles. The number of reported cases has increased since 2014 [8], [9]. In 45 percent of these cases, the first dose of vaccination had been administered [10]. Vaccination can prevent 92 percent of infections with a single dose and more than 99 percent with multiple doses [11], [12]. This is particularly intriguing given that a previous study has shown that changing the antigenic structure of the measles virus does not allow the virus to escape the body's immune response. One of the reasons for the emergence of the outbreak case was a drop in antibody levels caused by the passage of time in areas where measles had been eradicated. In other words, wild-type viruses provide no stimulus for antibody induction [13], [14].

According to various studies, the immunity obtained as a result of vaccine administration is influenced by both stable and dynamic factors. Sex, ethnic, and age are examples of static and uncontrollable factors. Age, exposure to environmental antigens, prior infection and maternal passive immunity are some of the associated dynamic factors [15], [16], [17]. The effect of sex and ethnic on vaccine immune response 
is still unknown. A previous study found no association between biological sex and cellular and humoral response factors. Regarding racial differences, it comes to racial differences, African-American races have more antibodies and cell-mediated immunity responses than Caucasian races [18]. Vaccination failure was higher at 8 months of age compared to 9-11 months of age [19]. Mothers who acquired natural infection, on the other hand, had higher antibody levels than vaccinated mothers, suggesting a higher potential for maternal transmission [20]. As far as we know, no study has been conducted in Indonesia to evaluate the factors of immunological response in measles vaccination. In Indonesia, research is focusing on the determinants of vaccine coverage and its dynamics [21], [22], [23]. As a result, the goal of this study is to investigate the immune response determinants in measles vaccination in Indonesia.

\section{Materials and Methods}

\section{Subjects}

The children in this study were vaccinated against measles at the Plumbon Health Center in Cirebon, West Java, Indonesia. The inclusion criteria for this trial were children in good health, no history of past infection, and parents agreeing to participate in the study. Children who were sick had a history of previous infections, or whose parents refused to participate in the study were all excluded from the study.

\section{Vaccine}

The vaccine used is the Serum Institute India's Edmonston-Zagreb measles vaccine (Pune, India). This vaccine is a combination of the MR vaccine and another vaccine. The vaccine given is the first dose as part of an Indonesian vaccination program (Batch Number 0128W0780 and 0128W0800).

\section{Analysis of demographic factors}

Sex, ethnicity, and age are among the demographic factors examined. When administering the first dose of vaccination, demographic factor analysis was performed.

\section{Nutritional factor analysis}

Among the nutritional parameters investigated were body weight, height, mass index (BMI). Nutritional variables were assessed concurrently with the delivery of the first dose of immunization.

\section{Measles-specific neutralizing antibody}

assay

According to prior research, this antibody assay was assessed utilizing a plaque-reduction microneutralization technique and a recombinant measles virus strain [24]. Seropositivity was defined as an antibody level of $120 \mathrm{mlU} / \mathrm{ml}$ (disease protection was assumed) [25]. The minimum detectable antibody concentration in our analysis was $106.95 \mathrm{mlU} / \mathrm{ml}$.

\section{Flow cytometry}

The determination of measles-specific $T$ cells producing IFN-y was performed according to a previous studies [24], [26]. Surface antibodies against CD8 (PE/ Cy5 Anti-human CD8a Antibody, Biolegend, cat.no. 300910) and CD4 (FITC Anti-human CD4 Antibody, Biolegend, cat.no. 317408) were used to label cell suspensions. We used anti-IFN- $\gamma$ antibody (Biolegend, USA, cat.no. 502509) for intracellular cytokine staining. The flow cytometry acquisition and analysis software FACScalibur (Becton Dickinson, USA) was used.

\section{Statistical analysis}

The mean \pm standard deviation was used to present all data. For comparison, the student's t-test or Mann-Whitney test were applied. For each of the markers, linear regression was used to perform the association between the determinants. All analysis was conducted by SPSS software (IBM Corporation, New York City, USA). p-values of $<0.05$ were considered significant.

\section{Results}

Table 1 shows the 45 infants aged 9-11 months who got the Edmonston-Zagreb measles vaccine. There were only two ethnic variations among all subjects based on self-declared ethnicity. There were $37.1 \%$ of subjects who were Javanese and $62.9 \%$ of

Table 1: Subject characteristics according to demographic, anthropometric, and nutritional status

\begin{tabular}{lll}
\hline Variable & Categories & $\begin{array}{l}\text { Value or frequency } \\
(\%)\end{array}$ \\
\hline Age of child (months) & Female & $9.83 \pm 0.86$ \\
Sex of child & Male & $16(45.71)$ \\
& 9 months & $19(54.29)$ \\
Age at vaccination & $>9$ months & $17(48.57)$ \\
& Javanese & $18(51.43)$ \\
Ethnicity & Sundanese & $13(37.14)$ \\
\multirow{2}{*}{ Anthropometric } & Weight $(\mathrm{kg})$ & $22(62.86)$ \\
& Height $(\mathrm{cm})$ & $8.26 \pm 1.05$ \\
\multirow{2}{*}{ Nutritional status (BMI for age) } & BMl $\left(\mathrm{kg} / \mathrm{m}^{2}\right)$ & $68.67 \pm 3.00$ \\
& Normal (-2-+2 SD) & $17.52 \pm 1.69$ \\
& Undernourished (<-2 SD) & $32(91.42)$ \\
\hline BMI: Body mass index; SD: Standard of deviation. Value are presented as mean \pm standard of deviation,
\end{tabular}


Table 2: Specific antibody and cellular immunity according to subject's demographic and nutritional status

\begin{tabular}{|c|c|c|c|c|c|c|c|}
\hline Variable & Categories & Antibody (mIU/mL) & P-value ${ }^{a}$ & CD4 T cells secreting IFN- $\boldsymbol{\gamma}(\%)$ & $P$-value ${ }^{b}$ & CD8 T cells secreting IFN- $\boldsymbol{\gamma}(\%)$ & $P$-value ${ }^{b}$ \\
\hline Sex of child & Female & $453.57 \pm 386.10$ & 0.140 & $7.81 \pm 3.84$ & 0.445 & $5.19 \pm 3.53$ & 0.990 \\
\hline & Male & $259.42 \pm 160.30$ & & $6.83 \pm 3.62$ & & $5.20 \pm 3.43$ & \\
\hline Age at vaccination & $\begin{array}{l}9 \text { months } \\
>9 \text { months }\end{array}$ & $\begin{array}{l}369.12 \pm 363.05 \\
371.44 \pm 272.72\end{array}$ & 0.493 & $\begin{array}{l}7.86 \pm 3.17 \\
6.89 \pm 4.27\end{array}$ & 0.423 & $\begin{array}{l}6.02 \pm 3.05 \\
4.30 \pm 3.21\end{array}$ & 0.143 \\
\hline Ethnicity & $\begin{array}{l}\text { Javanese } \\
\text { Sundanese }\end{array}$ & $\begin{array}{l}460.17 \pm 394.50 \\
317.11 \pm 257.83\end{array}$ & 0.226 & $\begin{array}{l}7.20 \pm 3.26 \\
7.46 \pm 4.04\end{array}$ & 0.842 & $\begin{array}{l}4.28 \pm 2.35 \\
5.73 \pm 3.88\end{array}$ & 0.232 \\
\hline Nutritional status & $\begin{array}{l}\text { Normal } \\
\text { Undernourished }\end{array}$ & $\begin{array}{l}383.73 \pm 329.24 \\
240.95 \pm 88.10\end{array}$ & 0.811 & $\begin{array}{l}7.30 \pm 3.77 \\
8.04 \pm 3.70\end{array}$ & 0.750 & $\begin{array}{l}5.29 \pm 3.50 \\
4.18 \pm 2.88\end{array}$ & 0.602 \\
\hline
\end{tabular}

Sundanese. From anthropometric measurement, the mean weight of the subjects was $8.261 .05 \mathrm{~kg}$, while the mean length and mean body mass index were $68.673 .00 \mathrm{~cm}$ and $17.521 .69 \mathrm{~kg} / \mathrm{m} 2$ respectively. There were three subjects classified as undernourished based on the BMI for age in the WHO growth chart. All of the study participants were in healthy condition and had never had a measles vaccination before nor had a measles natural infection.

Table 2 shows comparison between antibody immune titers, CD4 T or CD8 T cells that produce IFN- $\gamma$ according to demographic factors. Boys had higher immune titers to antibodies than girls, but it was not statistically significant $(p>0.05)$. In terms of CD4 or CD8 T cells that produce IFN- $\gamma$, there was no significant difference between both subjects $(p>0.05)$. The Javanese have higher antibody immune titers than the Sundanese but the difference is insignificant $(p>0.05)$. This insignificant finding was also observed in IFN- $\gamma$ producing CD4 or CD8 T cells between Javanese and Sundanese, $(p>0.05)$. There was no difference in postimmunization immune response $(p>0.05)$ between groups that received the vaccine at 9 months and groups that received the vaccine after 9 months. The normal BMI group had greater antibody immune titers than the low BMI group, although the difference was not statistically significant $(p>0.05)$.

Table 3 depicts the relationship between demographic factors and post-immunization immune responses. Measles-specific antibody levels were not associated with sex, age, or ethnicity $(p>0.05)$. There was no correlation $(p>0.05)$ between measlesspecific antibody levels and body weight, height, or BMI. Anthropometric indices were also unassociated with measles-specific T cells producing IFN- $\gamma(p>0.05)$. The findings of this study did not show an association between demographic, anthropometric characteristics, and humoral/cellular immune responses to measles vaccine.

Table 3: Associations between demographic and anthropometric on specific antibody and celular immunity

\begin{tabular}{llll}
\hline Variable & Antibody & $\begin{array}{l}\text { CD4 T cells secreting } \\
\text { IFN- } \gamma\end{array}$ & $\begin{array}{l}\text { CD8 T cells } \\
\text { secreting IFN- } \gamma\end{array}$ \\
\hline Sex of child & 0.057 & 0.445 & 0.990 \\
Age at vaccination & 0.491 & 0.617 & 0.601 \\
Ethnicity & 0.202 & 0.842 & 0.232 \\
Body weight & 0.051 & 0.766 & 0.320 \\
Body length & 0.427 & 0.190 & 0.900 \\
BMI & 0.053 & 0.976 & 0.787 \\
\hline Value is presented as $P$ value from linear regression test; $P<0.05$ was considered significant statistically; \\
BMl: Body mass index, IFN- $\gamma$ : Interferon- $\gamma$
\end{tabular}

BMI: Body mass index, IFN- $\gamma$ : Interferon- $\gamma$.

\section{Discussion}

Seropositive control and low vaccine efficiency are multifaceted and depend on the vaccination program's capability, vaccine potency, and host characteristics (particularly the immune system as a consequence of age and nutritional status) [27]. Vaccination rates were higher in boys than in girls, but not by a significant statistically. This suggests that sex has no effect on the development of post-vaccination immune responses. This finding contradicts previous study which found that after receiving the EdmonstonZagreb vaccine, girls' antibodies were higher than boys' [28].

In this study, there was no difference in postimmunization immune response between immunizations given at 9 months of age versus vaccines given after 9 months of age. This finding suggests that the age of the immunization vaccine is not a factor in the development of an adequate immune response. This finding is consistent with previous study, which found that age at first vaccine administration had no effect on seroconversion or long-term seropositivity to measles [4]. There was also no significant difference between the Javanese and the Sundanese in this study. This finding suggests that ethnic factors have no effect on immune response, especially in ethnic groups from Indonesia. When it comes to racial differences, African-American races have more antibodies and cell-mediated immunity responses than Caucasian races [18].

Poor nutritional status suppresses cellmediated immunity and contributes to the emergence of vaccine-induced complications [29], [30], [31]. There were no significant variations in antibody titers or CD4 or CD8 T cells secreting IFN-y between the low BMI and normal BMI groups, according to this study. This shows that an adequate immune response can be achieved in both good and poor nutritional conditions. This finding agrees with previous findings [32], but contradicts other studies that show a reduced immune response in children with poor nutritional status [33].

Overall, the study's weaknesses include the small number of samples, fact that it was only conducted at one center rather than a multi-center study, and the involvement of only two tribes. The next study will focus on a larger sample size, multiple centers, and various ethnic in Indonesia. 


\section{Conclusions}

It was determined that sex, ethnicity, age, and nutritional state had no effect on immunological response to measles vaccination. As a result, there is no barrier to seroconversion and optimal immunological accomplishment when the children in this trial get the Edmonston-Zagreb measles vaccination. In other words, these factors have no effect on the effectiveness of measles vaccination-induced immunity.

\section{Recommendations}

The administration of the Edmonston-Zagreb measles vaccine to the children in this study presents no barriers to seroconversion and optimal immune achievement, indicating that this vaccine is feasible and effective for children in Indonesia.

\section{Ethical Approval}

The Health Research Ethics Committee, Faculty of Medicine, Brawijaya University, Malang, East Java, Indonesia, approved this study (No:250/ EC/KEPK-S3/09/2019). The subject's parents were informed and signed informed consent forms.

\section{Authors Contributions}

TNHR, WB, IWAW, HMSCK, NSB conceived and designed the experiments; TNHR, TLS performed the experiments; TNHR, TLS analyzed and interpreted the data; TNHR, WB, NSB contributed reagents, materials, analysis tools or data; TNHR, WB, TLS wrote the paper. All authors have critically reviewed and approved the final draft and are responsible for the content and similarity index of the manuscript.

\section{References}

1. de Vries R, Duprex W, de Swart R. Morbillivirus infections: An introduction. Viruses. 2015;7(2):699-706. https://doi org/10.3390/v7020699 PMid:25685949

2. Mina MJ, Kula T, Leng $\mathrm{Y}$, Li M, de Vries RD, Knip M, et al.
Measles virus infection diminishes preexisting antibodies that offer protection from other pathogens. Science. 2019;366(6465):599-606. https://doi.org/10.1126/science. aay6485

PMid:31672891

3. Rota PA, Moss WJ, Takeda M, de Swart RL, Thompson KM, Goodson JL. Measles. Nat Rev Dis Primers. 2016;14(2):16049. https://doi.org/10.1038/nrdp.2016.49

PMid:27411684

4. Xu J, Doyon-Plourde P, Tunis M, Quach C. Effect of early measles vaccination on long-term protection: A systematic review. Vaccine. 2021;39(22):2929-37. https://doi.org/10.1016/j. vaccine.2021.04.012

PMid:33926750

5. Zmerli O, Chamieh A, Maasro E, Azar E, Afif C. A challenging modified measles outbreak in vaccinated healthcare providers. Infect Prevent Pract. 2020;3(1):100105. https://doi. org/10.1016/j.infpip.2020.100105

PMid:34368732

6. World Health Organization. Regional Office for the Western Pacific. Measles Elimination Field Guide. Manila: WHO Regional Office for the Western Pacific; 2013. Available from: https:// www.apps.who.int/iris/handle/10665/207664. [Last accessed on 2021 Jan 02]. https://doi.org/10.1093/ww/9780199540884.013. u248873

7. World Health Organization. Measles Vaccines: WHO Position Paper Recommendations. Vaccine. Geneva: World Health Organization; 2017. https://doi.org/10.1016/j. vaccine.2017.07.066

8. Sitepu FY, Depari E, Mudatsir M, Harapan H. Being unvaccinated and contact with measles cases as the risk factors of measles outbreak, North Sumatera, Indonesia. Clin Epidemiol Global Health. 2020;8(1):239-43. https://doi.org/10.1016/j. cegh.2019.08.006

9. Hartoyo E, Wiyatno E, Jaya UA, Ma'roef CN, Moganin C Myint KS, et al. Occurrence of measles genotype D8 during a 2014 outbreak in Banjarmasin, South Kalimantan, Indonesia. Int J Infect Dis. 2017;54:1-3. https://doi.org/10.1016/j. ijid.2016.10.029 PMid:27825950

10. Kementrian Kesehatan RI. Profil Kesehatan Indonesia Tahun 2017. Jakarta: Kementerian Kesehatan RI; 2018. Available from: https://www.kemkes.go.id/resources/download/pusdatin/profilkesehatan- indonesia/Profil-Kesehatan-Indonesia-tahun-2017. pdf. [Last accessed on 2021 Jan 05]. https://doi.org/10.7454/ epidkes.v3i2.3176

11. Uzicanin A, Zimmerman L. Field effectiveness of live attenuated measles-containing vaccines: a review of published literature. J Infect Dis. 2011;204(1):S133-48. https://doi.org/10.1093/ infdis/jir102

PMid:21666154

12. Yeung LF, Lurie P, Dayan G, Eduardo E, Britz PH, Redd SB, et al. A limited measles outbreak in a highly vaccinated US boarding school. Pediatrics. 2005;116(6):1287-91. https://doi. org/10.1542/peds.2004-2718

PMid: 16322148

13. Bitzegeio J, Majowicz S, Matysiak-Klose D, Sagebiel D, Werber D. Estimating age-specific vaccine effectiveness using data from a large measles outbreak in Berlin, Germany, 2014/15: Evidence for waning immunity. Eurosurveillance. 2019;24(17):1800529. https://doi.org/10.2807/1560-7917. es.2019.24.17.1800529 PMid:31039834

14. Hughes SL, Bolotin S, Khan S, Li Y, Johnson C, Friedman L. The effect of time since measles vaccination and age at first dose on measles vaccine effectiveness-a systematic 
review. Vaccine. 2020;38(3):460-9. https://doi.org/10.1016/j. vaccine. 2019.10 .090

15. Kampmann B, Jones CE. Factors influencing innate immunity and vaccine responses in infancy. Philos Trans $R$ Soc Lond $B$ Biol Sci. 2015;370:1-5. https://doi.org/10.1098/rstb.2014.0148 PMid:25964459

16. Van Loveren H, Van Amsterdam JG, Vandebriel RJ, Kimman TG, Rümke HC, Steerenberg PS, et al. Vaccine-induced antibody responses as parameters of the influence of endogenous and environmental factors. Environ Health Perspect. 2001;109(8):757-64. https://doi.org/10.1289/ehp.01109757 PMid:11564609

17. Metcalf CJ, Klepac P, Ferrari M, Grais RF, Djibo A, Grenfell BT. Modelling the first dose of measles vaccination: The role of maternal immunity, demographic factors, and delivery systems. Epidemiol Infect. 2011;139(2):265-74. https://doi.org/10.1017/ s0950268810001329

PMid:20525415

18. Voigt EA, Ovsyannikova IG, Haralambieva IA, Kennedy RB, Larrabee BR, Schaid DJ, et al. Genetically defined race, but not sex, is associated with higher humoral and cellular immune responses to measles vaccination. Vaccine. 2016;34(41):4913-19. https://doi.org/10.1016/j. vaccine.2016.08.060 PMid:27591105

19. Yan R, He H, Zhou Y, Xie S, Deng X, Tang Y. Study on factors associated with seroprotection after measles vaccination in children of 6-14 years in Eastern China. Vaccine. 2019;37(36):5185-90. https://doi.org/10.1016/j. vaccine.2019.07.075

PMid:31377078

20. Muthiah N, Galagoda G, Handunnetti S, Peiris S, Pathirana S. Dynamics of maternally transferred antibodies against measles, mumps, and rubella in infants in Sri Lanka. Int J Infect Dis. 2021;107:129-34. https://doi.org/10.1016/j.jijd.2021.04.002 PMid:33895406

21. Harapan H, Shields N, Kachoria AG, Shotwell A, Wagner AL. Religion and measles vaccination in Indonesia, 1991-2017. Am J Prev Med. 2021;60(1):S44-52. https://doi.org/10.1016/j. amepre.2020.07.029 PMid:33189503

22. Fernandez R, Anu Rammohan A, Awofeso N. Correlates of first dose of measles vaccination delivery and uptake in Indonesia. Asian Pac J Trop Med. 2011;4(2):140-5. https://doi.org/10.1016/ s1995-7645(11)60055-2 PMid:21771439

23. Hardhantyo M, Chuang YC. Urban-rural differences in factors associated with incomplete basic immunization among children in Indonesia: A nationwide multilevel study. Pediatr Neonatol. 2021;62:80-9. https://doi.org/10.1016/j.pedneo.2020.09.004

24. Nurlatifah HR, Barlianto W, Wiyasa IW, Kusuma HM, Sari TL, Bachtiar NS. Analysis of specific antibody and cellular immune response to first-dose measles vaccine EdmonstonZagreb in 9-month-old infants. Allergol Immunopathol (Madr). 2021;49(3):193-201. https://doi.org/10.15586/aei.v49i3.6

\section{PMid:33938206}

25. Njie-Jobe J, Nyamweya S, Miles DJ, van der Sande $M$ Zaman S, Touray E, et al. Immunological impact of an additional early measles vaccine in Gambian children: Responses to a boost at 3 years. Vaccine. 2012;30(15):2543-50. https://doi. org/10.1016/j.vaccine.2012.01.083

PMid:22314136

26. Nelson AN, Putnam N, Hauer D, Baxter VK, Adams RJ, Griffin DE. Evolution of T cell responses during measles virus infection and RNA clearance. Sci Rep. 2017;7(1):1-10. https:// doi.org/10.1038/s41598-017-10965-z

PMid:28904342

27. Ashbaugh HR, Cherry JD, Hoff NA, Doshi RH, Alfonso VH, Gadoth A, et al. Measles antibody levels among vaccinated and unvaccinated children 6-59 months of age in the Democratic Republic of the Congo, 2013-2014. Vaccine. 2020;38(9):2258-65. https://doi.org/10.1016/j.vaccine.2019.09.047 PMid:32057333

28. Martins C, Garly ML, Bale C, Rodrigues A, Benn CS, Whittle $\mathrm{H}$, et al. Measles antibody levels after vaccination with Edmonston-Zagreb and Schwarz measles vaccine at 9 months or at 9 and 18 months of age: A serological study within a randomised trial of different measles vaccines. Vaccine. 2013;31(48):5766-71. https://doi.org/10.1016/j. vaccine.2013.08.044

PMid:23994379

29. Carney JM, Warner MS, Borut T, Byrne W, Ament M, Cherry JD, et al. Cell-mediated immune defects and infection: A study of malnourished hospitalized children. Am J Dis Children. 1980;134(9):824-7. https://doi.org/10.1001/ archpedi.1980.02130210008003

PMid:7416105

30. Neumann CG, Lawlor GJ Jr., Stiehm ER, Swenseid ME, Newton J, Herbert $\mathrm{J}$, et al. Immunologic responses in malnourished children. Am J Clin Nutr. 1975;28(2):89-104. https://doi.org/10.1093/ajcn/28.2.89 PMid:803774

31. Spencer PS, Mazumder R, Palmer VS, Lasarev MR, Stadnik RC, King $P$, et al. Environmental, dietary and case-control study of nodding syndrome in Uganda: A post-measles brain disorder triggered by malnutrition? J Neurol Sci. 2016;369:191-203. https://doi.org/10.1016/j.jns.2016.08.023

PMid:27653888

32. Moore SE, Goldblatt D, Bates CJ, Prentice AM. Impact of nutritional status on antibody responses to different vaccines in undernourished Gambian children. Acta Paediatr. 2003;92(2):170-6. https://doi.org/10.1111/j.1651-2227.2003. tb00522.x

PMid: 12710642

33. Dao H, Delisle H, Fournier P. Anthropometric status, serum prealbumin level and immune response to measles vaccination in Mali children. J Trop Pediatr. 1992;38(4):179-84. https://doi. org/10.1093/tropej/38.4.179

PMid:1527814 